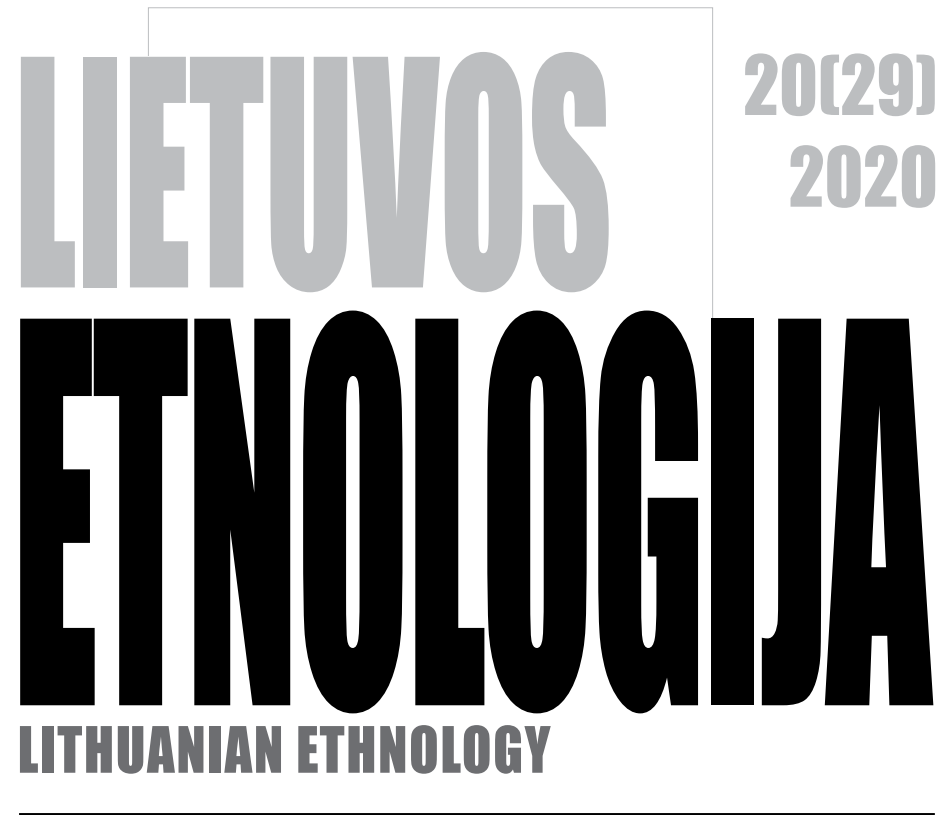

STUDIES IN SOCIAL ANTHROPOLOGY AND ETHNOLOGY

LIETUVOS ISTORIJOS INSTITUTAS

LITHUANIAN INSTITUTE OF HISTORY

VILNIUS 2020 
Lietuvos etnologija: socialines antropologijos ir etnologijos studijos - mokslinis etnologijos ir socialinès ir kultūrinès antropologijos žurnalas. Jame spausdinami recenzuojami straipsniai, konferenciju pristatymai, knygu recenzijos ir apžvalgos, kurių temos pirmiausia apima Lietuvą ir Vidurio/Rytų Europą. Žurnalas pristato mokslo aktualijas ir skatina teorines bei metodines diskusijas. Tekstai skelbiami lietuvių arba anglų kalba.

Lithuanian Ethnology: Studies in Social Anthropology and Ethnology - is a peer reviewed journal of ethnology and social and cultural anthropology. It publishes articles, conference presentations, book reviews and review articles, which may be in Lithuanian or English, primarily focused on Lithuania, Central and Eastern Europe. The journal represents current debates and engages in methodological discussions.

\section{REDAKCINĖ KOLEGIJA / EDITORIAL BOARD}

Vytis Čiubrinskas (vyriausiasis redaktorius / Editor-in-Chief)

Vytauto Didžiojo universitetas / Vytautas Magnus University, Kaunas, Lithuania

Auksuolè Čepaitienè

Lietuvos istorijos institutas / Lithuanian Institute of History, Vilnius, Lithuania

Jonathan Friedman

Kalifornijos universitetas / University of California, San Diego, USA

Chris Hann

Maxo Plancko socialinés antropologijos institutas / Max Planck Institute for Social Anthropology,

Haale / Saale, Germany

Jonathan Hill

Pietu Ilinojaus universitetas / Southern Illinois University, Carbondale, USA

Neringa Klumbytè

Majamio universitetas / Miami University, Ohio, USA

Ullrich Kockel

Heriot-Watt universitetas / Heriot-Watt University, Edinburgh, UK

Orvar Löfgren

Lundo universitetas / Lund University, Sweden

Jonas Mardosa

Vytauto Didžiojo universitetas / Vytautas Magnus University, Kaunas, Lithuania

Žilvytis Šaknys

Lietuvos istorijos institutas / Lithuanian Institute of History, Vilnius, Lithuania

REDAKCINĖS KOLEGIJOS SEKRETORĖ / EDITORIAL ASSISTANT

Danguolè Svidinskaite

Lietuvos istorijos institutas / Lithuanian Institute of History, Vilnius, Lithuania

Leidyklos adresas / Address of the Publisher: Redakcinès kolegijos kontaktai / Editorial inquiries: Lietuvos istorijos institutas

Kražių g. 5, LT-01108 Vilnius

El. paštas / E-mail: etnolog@istorija.lt

$<w w w . i s t o r i j a . l t>$

Žurnalas registruotas / The Journal indexed in:

European Reference Index for the Humanities (ERIH)

EBSCO Publishing: Academic Search Complete, Academic Search Ultimate, Energy and Power Source, SocINDEX with Full Text, Sociology Source Ultimate

Modern Language Association (MLA) International Bibliography

Leidybą finansavo Lietuvos mokslo taryba pagal Valstybinę lituanistinių tyrimų ir sklaidos 2016-2024 metų programą (Sutartis Nr. S-LIP-19-58) 
European Anthropologies. Andrés Barrera-González, Monica Heintz, Anna Horolets (eds). New York, Oxford: Berghahn, 2020[2017]. 296 p.: illustr.

In the history of anthropology, Europe as a subject is generally regarded as a late-comer, and, as Nigel Rapport observed with reference to an anthropology of Britain, inferior to 'a proper anthropology' that finds its object of study elsewhere (Rapport, Nigel. 2002. 'Best of British!': An Introduction to the Anthropology of Britain, N. Rapport (ed.). British Subjects: An Anthropology of Britain: 3-23. Oxford: Berg). This perception is, of course, thoroughly Anglo-centric, and reflects the historically dominant position of British social anthropology more than it reflects the historical actuality. An early volume of essays on the anthropology of Europe (Goddard, Victoria A.; Llobera, Josep R.; Shore, Cris (eds). 1994. The Anthropology of Europe: Identity and Boundaries in Conflict. Explorations in Anthropology. Oxford: Berg) is an inadvertent testimony to this perspective, with a bibliography including very few authors from outside the Anglo-American universe of discourse, and hardly any sources in any of the languages spoken in Europe. Thus, ignoring the substantial (if often controversial) contributions 'from within', this version of an anthropology of Europe remained caught in an approach to 'the other' that anthropology studying 'proper' (i.e. exotic) subjects was by then supposed to have overcome. 'Europe' was anthropology's last remaining frontier, its ultimate 'other'. Gerholm and Hannerz drew attention to the multitude of anthropologies that existed in various guises (Gerholm, Thomas; Hannerz, Ulf. 1982. Introduction: The Shaping of National Anthropologies, Ethnos 47(1-2): 5-35); and others, including the present reviewer, highlighted the fact that the anthropological study of European societies had a history going back at least as far as the colonial observation of the colonised exotic peoples, even if the study of the European peasantry, and later of proletarian and deviant subcultures, had an air of what Bausinger called Binnenexotik (internal exoticism) about it. The 1990s and early 2000s saw an increasing convergence between an anthropology of Europe influenced largely by American cultural anthropology, and the various national traditions of a European ethnology (by whatever name the Vielnamenfach was known), reflected in the foundation of the European Association of Social Anthropologists (EASA) and the resurgence of the Société Internationale d'Ethnologie et de Folklore (SIEF), with many contemporary scholars being active in both, even though anthropology and ethnology, where they coexist in the same university, are usually based in different faculties.

It is against this backdrop that the series of workshops on which the present volume is based took place over a number of years, associated with the Europeanist network in the EASA. Following a wide-ranging introduction by the editors, skilfully mapping out key themes and connections, the volume examines 11 substantive examples of European approaches to anthropological studies: Portugal, the German-language area, Russia, Italy, France, Finland, Lithuania, Poland, Slovakia, Croatia and Greece. Besides its regional focus, each of these chapters also addresses a particular broader issue, or set of issues, and charts the historical evolution of the discipline in its respective national context. Interesting similarities and differences emerge, and while none of this is particularly new to those of us engaged in the anthropological study of Europe 'from within', there is much to be learnt here for anyone acculturated within the monolingual 
traditions of British social or American cultural anthropology. An attentive reader will, for example, pick up on the contrast between a relatively integrated French ethnology that encompasses anthropology and ethnology/folklore more harmoniously than the divergent traditions in Italy; the curious position of Finland, emerging with a distinct identity of its own between its major neighbours, Russia and Sweden (which, given its broader influence in this field, is strangely missing from this collection); the political role of anthropological studies in small-state post-colonial nationbuilding, exemplified by Lithuania, and its contrast with similar small states in different historical contexts, such as Slovakia or Croatia; the problematics arising for early field sites and topics of an anthropology of Europe, exemplified by Greece (Ireland, a major field of early anthropology of Europe that would raise important issues in both theory and practice, is also missing from the collection); or the difficult negotiations of concepts and approaches in the light of a history of political abuse in the German-speaking areas.

Given the historical significance of British social anthropology, and the condescending view of any 'anthropology at home' in the British context as an amateur antiquarian pursuit not worthy of a university presence (Kockel, Ullrich. 2008. Turn- ing the World Upside Down: Towards a European Ethnology in (and of) England, M. Nic Craith et al. (eds). Everyday Culture in Europe: Approaches and Methodologies. Progress in European Ethnology: 149-163. Aldershot: Ashgate), a chapter on Britain, discussing the contemporary significance of the clear divergence between the constituent parts of the United Kingdom, would have been desirable to round off the collection. Having produced a few edited volumes over the years, this reviewer is acutely aware that there are limits to what can be included in any edited collection, and that editors must make choices. If an overall word limit had to be observed, restricting all contributions to, say, 15 pages each, could have given sufficient space to accommodate the addition of the three chapters indicated without loss of substance. This volume could have been strengthened considerably by more evident thematic structuring of the contributions. While the editors' introduction makes suitable reference to the wider issues and the wider national contexts, and clearly lays out a potential thematic structure, that structure remains implicit, and there is no obvious logic to the sequence of the chapters. Having said that, the volume serves very well as an introductory overview for a thematic series and is a valuable reference book for anyone interested in the anthropological study of Europe 'from within'.

Ullrich Kockel 